\title{
A Multidimensional View of Faculty Perceptions of Organizational Change at a Division I Football Bowl Subdivision (FBS) Power 5 Institution
}

\author{
Cherese F. Fine, Ph.D. \\ Clemson University \\ Joseph N. Cooper, Ph.D. \\ University of Massachusetts (UMass) Boston
}

\begin{abstract}
The structure of big-time intercollegiate athletics has evolved significantly since its inception in the late 19th century. Changes have included the establishment of the National Collegiate Athletic Association (NCAA), competition rules, academic eligibility standards, amateurism bylaws, and exorbitant revenues and salaries for athletic departments and their respective staffs. One prominent group that has been vocal against the increased commercialization of intercollegiate athletics are faculty. Although previous research has examined the establishment of faculty-led reform groups, there is a dearth of scholarly literature on faculty perceptions of institutional morphing at the exo- and meso-levels. As such, the purpose of this study was to engage in a multidimensional exploration of faculty perceptions of organizational change at a Division I big-time institution. A phenomenological case study approach including in-depth individual interviews with faculty members offered rich insights into the complexity of and challenges associated with organizational change including both benefits and detriments. Implications for policy and practice are discussed.
\end{abstract}

Keywords: intercollegiate athletics, faculty perceptions, National Collegiate Athletic Association (NCAA), phenomenology

A longstanding debate in higher education within the United States (U.S.) has been determining the proper role of intercollegiate athletics since its inception in the early 1900s (Byers, 1995; Duderstadt, 2003; Sack \& Staurowsky, 1998; Sperber, 2000; Thelin, 1994). During the early twentieth century, along with safety concerns associated with the burgeoning popularity of football, there was growing resistance among faculty at prestigious postsecondary institutions who asserted that the presence and commercialization of athletics comprised academic integrity and educational missions (Duderstadt, 2003; Sack \& Staurowsky, 1998). For example, in 1929, the Carnegie Foundation published a scathing report highlighting the improprieties of big-time college sports, including academic devaluation and unethical institutional actions, that prioritized athletic success over the founding purposes of these educational institutions (Sack \& Staurowsky, 1998). In contrast, proponents of athletic commercialization argued from a functionalist perspective that these activities served as a vital source to strengthen institutional brand visibility, attachment, and equity among students, alumni, and the broader community (Sack, 2009). Notwithstanding, recent incidents of academic fraud at schools, such as the University of North Carolina at Chapel Hill, 
Florida State University, and the University of Memphis, to name a few, underscore the prevailing conflict between academics and athletics (Cooper, Nwadike, \& Macaulay, 2017). The increasing economic revenues generated by highly successful athletic programs has presented a paradox for institutional leaders (Southall \& Nagel, 2010; Sperber, 2000). In response to these changes, there have been a range of views expressed by the National Collegiate Athletic Association (NCAA; largely comprised of college presidents, athletic directors, conference commissioners, and to a lesser extent faculty in the form of Faculty Athletic Representatives [FARs] and other key stakeholders such as faculty reformists (Brand, 2006). Since faculty are the vanguard of institutions of higher education, it is important to explore their perspectives on how organizational changes, such as NCAA bylaws, conference realignment, and institutional shifts impact the academic, athletic, and social milieu at a specific institution. The current study fills this gap.

In an effort to maintain a healthy balance between academic integrity and athletic success, the NCAA has implemented a host of bylaws using eligibility standards as a tool to promote institutional, team, and individual accountability (Nwadike, Baker, Brackenbusch, \& Hawkins, 2016). For example, in response to growing criticisms from concerned faculty, in 1965 the NCAA instituted the 1.6 rule, which required prospective student-athletes to earn a high school grade point average (GPA) and incoming test scores that would predict a college GPA of 1.6 (Byers, 1995; Cooper et al., 2017). Despite the fact that establishing minimum academic standards was acknowledged by the academic community, many faculty were still discontented with the messaging of low performance standards for student-athletes (Sperber, 2000; Thelin, 1994). As a result, by 1972, the 1.6 rule was abolished (Byers, 1995). Subsequently, in 1986, the NCAA passed Proposition 48 (initially proposed in 1983), which increased pre-college enrollment admission standards including a minimum GPA of 2.0, required coursework, and baseline test scores on the Scholastic Aptitude Test (SAT) and/or American College Test (ACT) (Brown, 2014). In 1989, an updated version of Proposition 48 was proposed in the form of Proposition 42, which restricted athletic grant-in-aid to only full qualifiers versus full and partial qualifiers; however, due to the punitive nature of the proposal, it was rescinded in 1990. Later in 1992, Proposition 16 included a sliding scale whereby prospective student-athletes' eligible GPA and test scores could vary as opposed to a standardized GPA and test score for all incoming student-athletes (Brown, 2014). More recently, in 2003, the NCAA instituted the Academic Performance Program (APP), which included the creation of the graduation success rate (GSR) and academic progress rate (APR) metrics, along with corresponding penalty structures in an effort to hold institutions and teams accountable for student-athletes' academic performance and progress towards degree completion (Brown, 2014).

Faculty across the U.S. have consistently expressed their criticism of the ongoing changes in intercollegiate athletics. In fact, it was during the late twentieth century when faculty reform groups such as The Knight Commission on Intercollegiate Athletics (KCIA; established in 1989), The Drake Group (TDG; established in 1999), and The Coalition of Intercollegiate Athletics (COIA; established in 2002) were founded (Cooper et al., 2017; Sack, 2009). Each of these organizations offered distinct reform recommendations, but a common theme across all three was the criticism of the growing commercialization of intercollegiate athletics and the comprising academic integrity of institutions of higher education as a result of these changes. Previous scholars have examined macro-level NCAA changes (Ridpath, 2018; Sack, 2009), but given the complexity of institutional structures and the heterogeneity of faculty perspectives, there is a need for 
exploratory research focusing on understanding the nature of these views within specific milieu (i.e., a single Division I Power 5 institution). Hence, the current study incorporated a phenomenological case study approach to better understand how faculty at a big-time college sports institution perceived organizational change over time.

\section{Literature Review}

\section{The NCAA’s Collegiate Model and An Integrated View of Athletics from Faculty}

In order to understand faculty perceptions of organizational changes in response to the evolving role of big-time sports, it is important to first acknowledge the foundational principles undergirding the NCAA as well as the counter stances promulgated by the different faculty-led academic reform movements. In his memoir titled, Unsportsmanlike Conduct, Walter Byers, former NCAA Executive Director, outlined how the term student-athlete was conceptualized in concert with the ethic of amateurism (Byers, 1995). Dating back to the early twentieth century, the NCAA was committed to establishing a demarcation between intercollegiate athletics and professional sports. The primary delineating characteristics between the two entities was that student-athletes were not employees and thus, as students, they were restricted from earning compensation based on market value for their athletic abilities (see Schwarz [2011] for a critique of this cartel behavior). In addition, student-athletes were (and are) expected to fulfill academic eligibility standards set forth by the NCAA, whereas professional athletes are not held to these standards since their employers are not affiliated with institutions of higher education. As outlined in the previous section, the NCAA instituted bylaws throughout the mid- to late-twentieth century to promote their brand image as an academic-centered organization (Sack \& Staurowsky, 1998).

The most pronounced organizational change at the NCAA level occurred in 1964 when Byers introduced the term student-athlete (Byers, 1995). In response to growing workers' compensation lawsuits issued against the NCAA, Byers's legal team advised him to create a term that could be used throughout the association to more clearly distinguish the difference between intercollegiate athletes and professional athletes, since the latter were legally classified as employees with workers' compensation rights (Finkel \& Martin, 2013). Shortly thereafter, all NCAA documents and marketing materials infused the language student-athlete, which referred to individuals who were students at NCAA member institutions who participated in intercollegiate athletics as a co-curricular activity (or as an avocation) as opposed to engaging in labor for wages and associated benefits (Byers, 1995; Sack \& Staurowsky, 1998; Zimablist, 2001). Since the infusion of this language, the NCAA has sustained its non-profit status and propaganda campaign positing that intercollegiate athletics serves as an integral component of the educational missions of these institutions. In 1973, the NCAA created three divisional classifications (I, II, III) to delineate competition levels as well as distinct governing structures (NCAA, 2019). The aforementioned organizational changes were instituted with the aim of strengthening the NCAA brand as a leader in intercollegiate athletics in the U.S. that balanced competitive athletics with rigorous academics. 
Related to amateurism and student-athlete eligibility standards (e.g., 1.6 rule, Propositions 48, 16, and 42, and the APP), NCAA president (and notably a former university president and faculty member unlike Walter Byers) Myles Brand issued an organizational manifesto during the beginning of the 21 st century that outlined the purpose and benefits of the collegiate model (Brand, 2006). In concert with faculty perspectives that supported the integration of intercollegiate athletics into educational missions, Brand's functionalist faculty-centric perspective reflected what Sack (2009) described as the academic capitalist view of big-time college sports (this concept is discussed in greater detail later in this section). In his description of the collegiate model, Brand (2006) differentiated the standard view from the integrated view. According to Brand (2006), the standard view posits that intercollegiate athletics is an extracurricular activity similar to student government and campus organizations. Brand (2006) argued that faculty who adopt the standard view often support the notion that removing athletics from postsecondary institutions would not adversely affect the institution's bottom line. In other words, the standard view surmises that athletics can be complementary to the institution, but it is not necessary. The aforementioned view is accentuated by staunch critics of the NCAA who argue that commercialized athletics diminishes the educational fabric of colleges and universities via the erosion of academic integrity for athletic glory.

In contrast, Brand (2006) explained how the integrated view reflects the NCAA's position on the role of intercollegiate athletics, i.e., the collegiate model. The integrated view posits "that athletic programs are made part of the educational mission of the university...they play the same type of role as music and art and, perhaps, business and journalism...By focusing on the harmony between mind and body in education, athletics takes on a more central role" (pp. 16-17). The integrated view touts numerous positive benefits derived from intercollegiate athletics for stakeholders such as the campus community, alumni, city/town, state, and region. The adoption of this integrated view has resulted in exorbitant investments in intercollegiate athletics in terms of state-of-the-art facilities, coaches' salaries, recruiting budgets, student-athlete academic support services, coaches, staff, and administrators (Sperber, 2000). For example, the University of South Carolina (USC) spent $\$ 13.5$ million on the building of the Dodie Anderson Academic Enrichment Center and at the in-state rival school, Clemson University (CU), the budget for Vickery Hall (student-athlete academic support center) is $\$ 1.7$ million including 17 full-time staff and 75 student tutors (Sapakoff, 2008). Suffice to say, the integrated view of intercollegiate athletics combined with the favorable tax benefits afforded to NCAA member institutions by federal and state governments underscore how faculty and other stakeholders who adopt this view have influenced organizational change.

\section{College Sport Reform Efforts and Faculty Perspectives}

Despite the benefits associated with the NCAA and its commercialized institutional logics (Southall \& Nagel, 2010), not all faculty have embraced the integrated view/collegiate model of athletics promulgated by former President Myles Brand (Cooper et al., 2017; Sack, 2009). During the late 1980s and early 1990s, several faculty-led academic reform movements were established to counteract the prevailing trend of neoliberal capitalism at big-time college sport institutions (Gayles, Comeaux, Ofoegu, \& Grummert, 2018). KCIA is one of the most visible among these reform groups. Since their creation in 1989, they have published numerous reports outlining their recommendations for how to improve intercollegiate athletics (KCIA, 2019). The KCIA one-plus- 
three model is academic integrity, athlete welfare, and institutional accountability (Cooper et al., 2017). On their website, KCIA cite that their accomplishments are reflected in the fact that studentathletes' graduation rates have increased, championship eligibility standards are now connected to academic standards, and financial incentives are attached to academic success as a result of their lobbying efforts (KCIA, 2019).

Another prominent faculty reform group is TDG. Established in 1999, TDG focuses on academic integrity through institutional accountability and transparency (TDG, 2019). Annually, TDG presents the Robert Maynard Hutchins Award to a faculty or staff member who exhibits courage in the name of academic integrity within intercollegiate athletics. Former award winners include Mary Willingham (the famous whistleblower in the University of North Carolina at Chapel Hill [UNC-CH] academic scandal in 2014 and co-author of the book titled Cheated: The UNC Scandal, the Education of Athletes, and the Future of Big-Time College Sports) and Dr. Billy Hawkins (author of the critically acclaimed book The New Plantation: Black Athletes, College Sports, and Predominantly White Institutions). In addition, TDG publishes numerous position statements on issues ranging from student-athletes' rights to eligibility issues to facility excesses, to name a few.

The youngest of the three major academic reform groups is COIA. This organization was established in 2000 (COIA, 2019). The core beliefs of COIA include prioritizing the student role among student-athletes, critical scholarship on intercollegiate athletics, diversity and inclusion, and fiscal responsibility and transparency. COIA prioritizes faculty oversight of intercollegiate athletics and student-athlete integration into the campus community versus the ubiquitous trend of athletic isolation, or silozation. One of the distinct aspects of COIA is their emphasis on campus governance of intercollegiate athletics as opposed to a primary focus on the NCAA (COIA, 2019). Although, there are numerous similarities across KCIA, TDG, and COIA, Sack (2009) outlined differences in assumptions by each group related to the intersection of commercialization and academic values, the benefits and detriments of athletic scholarships, and the overarching purpose of higher education.

Faculty-led reform groups analyses revealed key insights about faculty perspectives on topics such as academic oversight, faculty governance, and fiscal oversight (Lawrence, Ott, \& Hendricks, 2009). Regarding academic oversight, the authors found that faculty were content with allowing professional staff to determine admissions decisions and thus, they were not interested in being overly involved in the recruitment process of prospective student-athletes (Lawrence et al., 2009). According to their study, rather than being most concerned about student-athletes' academic performance or athletic department involvement in academic support, faculty were most interested in reducing time constraints imposed upon student-athletes for athletic competition and the subsequent impact on their overall well-being (Lawrence et al., 2009). With respect to faculty governance, in contrast to COIA and American Association of University Professors (AAUP), findings revealed faculty place a low priority on governing intercollegiate athletics given their training, expertise, and role at the institution. However, faculty do tend to support those who serve as Faculty Athletic Representatives (FARs) and related roles to monitor academic integrity within athletics. In fact, they found that faculty view athletics largely as a "separate, commercialized enterprise, operating under its own rules" similar to the campus bookstore or food services (Lawrence et al., 2009, p. 78). Related to financial oversight, faculty on the whole were less 
informed about the budgeting processes for athletics and possessed mixed views on institutional subsidizing of these activities (Lawrence et al., 2009). Despite the valuable contribution of the aforementioned research, there is a dearth of empirical studies that have explored faculty perceptions of intercollegiate athletics (Cockley \& Roswal, 1994; Engstrand, 1995) and even these studies have focused on their views of the macro-level structure of big-time college sports. In contrast, the uniqueness of the current study lies in its focus on examining faculty perceptions at the meso-level at a single Division I Football Bowl Subdivision (FBS)/Power 5 institution. We argue that not only does this type of in-depth investigation build upon previous literature, but it also offers a more micro-level investigation into understanding how changes manifest at the institutional level and how faculty respond to these organizational changes.

\section{Theoretical Frameworks}

\section{Commercial Models of College Sport}

In an examination of faculty-led reform efforts, Sack (2009) outlined three conceptual models of commercial college sport. The three conceptual models are intellectual elitism, academic capitalism, and athletes' rights. Although these models are not an exhaustive overview of faculty perceptions on intercollegiate athletics, they offer a useful foundation for examining the perceptions of faculty in our study. According to Sack (2009), the intellectual elitism model posits that big-time college sports produce a net negative outcome on institutions of higher education. Proponents of the intellectual elitist view challenge the benefits associated with the corporate business model integrated in big-time college sports, including the use of special admissions for student-athletes and the purpose of athletic scholarships. Regarding special admissions, intellectual elitists argue the time demands associated with athletics along with the significant academic needs of students who are admitted through these policies are subsequently underserved and exploited. In terms of athletic scholarships, intellectual elitists view this arrangement as devaluing academics since coaches control the renewal of these funds, which is largely based on athletic performance with less emphasis on academic achievement and development (as opposed to eligibility; Sack, 2009).

The academic capitalism model views big-time sports as an integral part of the broader business model of higher education (Sack, 2009). Athletics serves as the proverbial front porch of the university and enhances institutional brand equity, i.e., awareness, association, perceived brand quality, and loyalty (Stotlar, 2013). Proponents of academic capitalism cite the various benefits associated with big-time college sports such as increased student applications (also referred to as the Flutie Effect), admissions selectivity, enrollment numbers, alumni donations, and corporate sponsorships, to name a few (Dosh, 2013). Brand's (2006) stance on the collegiate model highlights how college sport and higher education rely on commercialism to meet their respective missions (Sack, 2009). Academic capitalists also believe athletic scholarships is a mechanism to support deserving students in earning a valuable education; thus, career preparation (including in professional athletics) should be valued across the institution (Sack, 2009). The academic 
capitalism model views amateurism as an important ethic to uphold in intercollegiate athletics (Sack, 2009).

The athletes' rights model argues that athletes in big-time college sports should be viewed and treated as employees who receive the benefits therein, e.g., worker's compensation, equitable wages, etc. (Sack, 2009). Athletes' rights advocates, including faculty members such as Dr. Ellen Staurowsky at Drexel University who founded the College Athletes Rights and Empowerment Faculty Coalition (CARE-FC; CARE-FC, 2019; Cooper et al., 2017) and non-faculty led groups such as the College Athletes Players Association (CAPA) led by Ramogi Huma are examples of athletes' rights advocates (CAPA, 2019). Gayles and colleagues (2018) referred to the NCAA's current practices at the Division I level as reinforcing neoliberal capitalism and devaluing college athletes' academic and personal well-being. Along the same lines, Southall and Nagel (2010) purported that the commercial logics that undergird NCAA practices exploit college athletes, particularly those in the two highest revenue-generating sports of football and men's basketball. In sum, athletes' rights advocates assert college athletes (as opposed to the NCAA term studentathletes) deserve the protections and benefits afforded to both students and employees. Thus, these advocates surmise the principle of amateurism should be abolished and athletic scholarships should be modified to account for full employee benefits. The unionization of college athletes is another focal area for these advocates. Hence, the athletes' rights model directly challenges the NCAA's collegiate model (Sack, 2009). These three models are useful for categorizing faculty perceptions at the Division I Power 5 institution in this study.

\section{Multidimensional View of Attitudes Toward Organizational Change}

Drawing from the organizational management literature, Piderit (2000) theorized a multidimensional view of attitudes toward organizational change. According to the framework, organizations, the changes they pursue, and the responses from key stakeholders are complex and require nuanced analyses that account for evolving processes and perspectives over time. Within this model, Piderit (2000) delineates divergent responses to change as favorable, unfavorable (resistant), and indifferent, which can subsequently be reconceptualized as multiple dimensions of attitudes. When analyzing unfavorable responses to change, Piderit (2000) explained how these responses can be grounded in individuals' ethical principles as well as their view of what is legitimately in the best interest of the organization. In addition, often times when changes are presented, all stakeholders are not provided with equal access to information, which can influence unfavorable attitudes or resistance to change.

Moreover, the model outlines how responses to organizational change can occur in a cognitive state, emotional state, and/or behavioral state. Within each state, responses can vary from strong positive to strong negative (Piderit, 2000). Depending on the type and nature of the response, organizations can address these responses differently while valuing each of them equally. In her reconceptualization of multiple dimensions of attitude, Piderit (2000) outlined three dimensions of resistance to change: (a) cognitive, (b) emotional, and (c) intentional. The cognitive dimension refers to "an individual's beliefs about the attitude object" (Piderit, 2000, p. 786). This dimension of attitude is based on previous behaviors as well as expectations for future actions and intentions (organizationally and individually). When faculty assert that athletics should be viewed and treated similarly to other academic or professional department or unit on campus, this 
argument reflects a cognitive dimension of resistance to organizational change. An example of this cognitive dimension of resistance argument is the assertion that academic and athletic departments should receive comparable institutional subsidies as opposed to disproportionate funding. Piderit (2000) describes the emotional dimension as "an individual's feelings in response to the attitude object" (p. 786). When faculty feel their worth to the institution is devalued because the football or men's basketball coach at their school is paid a significantly higher salary for focusing on athletic success, this reflects an emotional dimension of an attitude. The intentional dimension of attitude focuses on the delineation between intention and behavior. An example of the intentional dimension of attitude is when faculty and athletic administrators agree that increasing funding for college athletes' academic support, i.e., tutors, is necessary for fulfilling the educational mission of the institution. More specifically, Piderit (2000) offered the following explanation for this dimension: "Whether the intentional dimension is sufficiently associated with individuals" cognitive or emotional responses to be treated as a dimension of an employee's attitude remains an empirical question in the context of an attitude about proposed organizational change" (pp. 786787).

Global evaluations or attitudes that take into account external forces can also influence the three dimensions of attitudes. For example, faculty who adopt an academic capitalist (Sack, 2009) view could argue deemphasizing athletics via investments or organizational change could yield negative outcomes for the institution. This stance is a byproduct of the economic trends associated with growing neoliberalism in the U.S., particularly reduced state support and increased privatization as well as the increasingly competitive higher education market. The benefit of the multi-dimensional model allows for nuanced analysis across different response states (cognitive, emotional, and intentional) or the "possibility of ambivalence in response to a particular change proposal" (Piderit, 2000, p. 787). In addition, the model is useful for examining the impact of both top-down, i.e., global attitudes, and bottom-up, i.e., cognitive/emotional/intentional, organizational change (Piderit, 2000). Within the current study, the multi-dimensional view of attitudes towards organizational change illuminate the ambivalence among faculty perceptions over time at a Division I FBS/Power 5 institution to ascertain a deeper understanding of meso- and micro-level processes related to neoliberal capitalism within big-time college sports. Understanding such ambivalence is vital for addressing issues threatening the integrity of intercollegiate athletics such as academic fraud, overemphasis on athletic revenue generation, and social isolation of college athletes from the general campus community. Given the institutionalized role of faculty at colleges and universities, it is important to examine how, when, why, and to what extent they agree or disagree with the current status of big-time college sports as it relates to serving the overarching purpose of institutions of higher education. Acquiring this knowledge can inform the development of effective strategies for stimulating faculty-led and collaborative reform efforts to optimize alignment between athletics and academics at Division I FBS/Power 5 institutions.

\section{Methods}

This study utilized a phenomenological case study approach to better understand how faculty at a big-time college sports institution perceived organization change over time. Phenomenology focuses on understanding the human experience and of the way things present themselves to us through such experience (Moustakas, 1994; Patton, 2002; Sokolowski, 2000). It 
focuses on descriptions of what people experience and how it is they experience what they experience (Patton, 2002). Case study research creates a firsthand understanding of people and events through the ability to examine a phenomenon in-depth within real-life context (Yin, 2003; 2006). Using both case study and phenomenology allows a comprehensive understanding of the experiences of participants at a single site.

\section{Site and Participants}

The site of the study is Blue Ridge University (BRU), an institution in the NCAA Division I Football Bowl Subdivision (FBS) that is currently ranked in the top 25 of US News Top Public Schools. An institutional pseudonym was used to preserve the anonymity of the school. The site is steeped in many traditions and athletics, in particular football, and has been an essential part of the institutions' brand. Since BRU is a prominent academic institution with high-profile sports, it was an optimal site to explore the phenomenon. The role of the participants was to gain insight about how the athletic-academic dynamic has changed over time at a site. Purposive sampling techniques were used to identify five faculty participants (see Table 1; Teddlie \& Yu, 2007). One retired and four current faculty members participated in the study with a range of 16 - 37 years of working at the site of the study. Faculty participants were selected based on whether they had a working relationship with the athletic department. A working relationship included teaching classes with enrolled student-athletes and serving on athletic committees. It was important to focus on individuals who have had some type of working relationship with the other area because they can provide a more accurate description of the interaction. Furthermore, interviewing faculty who have been at the institution for an extended time provides insight on how the institution has changed over time. 
Table 1

Participant Information

\begin{tabular}{|c|c|c|}
\hline Name & Years Working at BRU & Experience with Athletics \\
\hline Professor Welfare & 33 & $\begin{array}{c}\text { Faculty Senate } \\
\text { Athletic Council } \\
\text { NCAA Recertification Study } \\
\text { Teaching student-athletes }\end{array}$ \\
\hline Professor Integrity & 31 & $\begin{array}{c}\text { Faculty Athletic Representative } \\
\text { Athletic Council } \\
\text { Teaching student-athletes }\end{array}$ \\
\hline Professor Equity & 16 & $\begin{array}{c}\text { Faculty Senate } \\
\text { Athletic Council } \\
\text { Athletic Admissions Committee } \\
\text { Teaching student-athletes }\end{array}$ \\
\hline Professor Ethics & 30 & $\begin{array}{c}\text { Faculty Athletic Representative } \\
\text { Athletic Council } \\
\text { Teaching student-athletes }\end{array}$ \\
\hline Professor Alliance & 37 & $\begin{array}{l}\text { Teaching student-athletes } \\
\text { Former student-athlete }\end{array}$ \\
\hline
\end{tabular}

\section{Data Collection and Analysis}

Data sources consisted of phenomenological interviews, which is "an informal, interactive process and utilizes open-ended comments and questions" (Moustakas, 1994, p. 114). To better understand organizational change, it was important to interview those who have a lived experience, rather than secondhand experience (Patton, 2002). The participants' lived experiences provide a firsthand understanding of the athletic-academic dynamic over time. The interviews were conducted in person and recorded. Phenomenological analysis was used to analyze the interview transcripts. The process of horizontalization, reviewing every transcript with equal value, was used to identify every statement related to the phenomenon (Moustakas, 1994). The statements were then clustered into themes and organized into coherent textural description of the phenomenon (Moustakas, 1994; Patton, 2002). To ensure trustworthiness during this process, various strategies were employed, including member checking (Creswell, 2007; Harper \& Cole, 2012), where transcripts were sent to each participant for accuracy and authenticity, and a critical friend that provided feedback to help reduce researcher bias (Gordon, 2006). 


\section{Findings}

The data shared in the findings were extracted from a larger phenomenological case study conducted on the athletic-academic dynamic at BRU. The data were reanalyzed for the purpose of the current study. Participants shared their overall personal beliefs about athletics changing over time as well as how faculty at BRU perceive athletics. The analysis resulted in the following two themes: (a) Resistance to Change and (b) Adapters to Change. Before reporting the findings, it is important to give context of what has occurred at BRU over time. During the 1980s and 1990s, BRU athletics had many successes, which was attributed to their winning at-all-costs strategies. However, this mentality produced loose admissions policies for student-athletes and major controversies resulted in numerous NCAA infractions. The negative attention and debates surrounding athletics resulted in academics and athletics clashing intensely. Through the controversies, athletics and academics decided to work together to try to avoid future violations. Over time, they created policies that improved the academic process for student-athletes and focused on winning within the rules. During the late 1990s and early 2000s, the president of the institution was committed to a long-term goal of BRU being successful in both academics and athletics. This was the beginning of BRU's goal to become a top 25 athletic program that wins championships across multiple sports. This also resulted in BRU having to participate in the athletics arms race to be successful, which included renovating and building new facilities and paying top dollar to have high caliber coaches to attract top student-athletes. While BRU has not had any major controversies in the last 20 years, there is still some tension between the athletics department and academic units. The building of expensive and elaborate new facilities versus lack of renovating academic buildings, high-salaried coaching staff versus lower-salaried faculty, and the lack of knowing what is occurring in athletics contributes to the current perception that BRU prioritizes athletics over academics.

\section{Intellectual Elitists: Faculty Perceptions as Resistance to Change}

The evolution of intercollegiate athletics has resulted in increased commercialization, while also bringing positive and negative attention to colleges and universities. Faculty that are very critical of the commercialization of athletics are considered intellectual elitists (Sack, 2009). As athletics continues to become an integral part of the university, faculty that hold intellectual elitist views may resist the changes that are occurring, especially if they believe it is adversely impacting the academic mission of the institution. Professor Welfare expressed the sentiment of intellectual elitists, "The more we win, the more difficult it is to have that athletic-academic tie because the shift is more toward the winning, in some ways, more toward the athlete part of the student-athlete." The cognitive dimension in Piderit's (2000) model focuses on the beliefs toward an issue. Four of the five faculty participants described their beliefs in terms of how the professionalization of athletics, primarily football and basketball, and the desire to win has negatively impacted the academic side of BRU.

The big-timeness of football and basketball right now, I don't think it really harmonizes with the general academic mission of an institution. So basically it has become this entertainment enterprise. And you have a lot of arguments about whether we exploit the student-athletes or whatever. But, it's not the same as enabling a group of kids to be part 
of a team and getting the benefits and being part of a team, that doesn't seem to be the motivation, and the team being a part of the institutions. (Professor Integrity)

It's one thing if the football team is going to be at [Flatlands Tech] on a Thursday night. So they gotta leave Wednesday. They're gonna be gone Wednesday night, Thursday, and probably part of Friday. That's sort of a legitimate excused absence. But if the coach says that, "yeah they're not leaving til 5:00 on Wednesday but we also have to have a team meeting at 2:00 on Wednesday that everyone is required to be at." So you have to make the team meeting and that all professors should cancel their classes for these athletes and then schedule a makeup assignments. That kind of stuff, faculty don't react really well to. I don't even really like the idea that you're going to the game but I'm willing to do that. (Professor Equity)

There are people on this campus who are concerned about they don't ever want to put BRU at a competitive disadvantage in athletics. So a lot of these decisions and policies are not driven by what's best for the student or by what's best academically. A lot of it is driven by what's [Mountain State] doing, what's [River Tech] doing, and we don't want to do anything that would put us, recruiting-wise for instance, beyond those places. It's an interesting dynamic. It is this sort of different goals in the admissions process and my goal obviously is academics and his goal may be winning football games and the person caught in the middle of that is a 19 year old kid from wherever who is sitting in my classroom 8:30 in the morning and on the field 4:00 in the afternoon. Can he do both? (Professor Welfare)

I don't think your academic offerings should be designed to assist your athletic department become successful. I think it does happen. I think there are courses that have been introduced that has to be with faculty members that are willing to do it. But I think we are guilty as many schools are of tweaking our academics to make it more attractive to those we want to recruit and retain and do well that help our sports team. I don't agree with that, but I do believe that does exist. (Professor Ethics)

The big-time nature of athletics results in academics catering to athletics through offering courses specifically to student-athletes or allowing them to miss many classes due to travel and other athletic commitments. Intellectual elitists believe the desire of athletic department personnel to remain competitive, puts the academic side of the institution at a disadvantage.

The intellectual elitists in the current study would overall support athletics if it was uncommercialized. Professor Welfare shared how an ideal sports model should focus on developing well-rounded individuals rather than winning:

I think if athletics views a sport as a money generator, in which football and basketball are, I wish they would go away to be perfectly blunt. If athletics really viewed a sort of developing sound mind, sound body, people who are physically healthy and well, I think that's a great model. I think that is the model for a lot of people like in track, or tennis and rowing, I think there is much more of a model of certain well-rounded person who athletics is an important piece of their life but not the main reason they're at BRU...I'd 
have a hard time accepting from anyone that football, for instance, doesn't exist on this campus to raise money. You'd have a hard time convincing me it's to make sure those guys here playing football leave here well-rounded individuals prepared for life.

Professor Equity did not share their personal perspective, but shared a couple of thoughts about how faculty would be fine with athletics if the model was not professionalized:

I think a lot of faculty would like us to have a football team in the same way [Elite University] has a football team. Yeah there's a football team, but the few academics that are interested in that kind of stuff go out there, but they never win unless they play [Ivy University] and nobody really goes to the games and cares that much.

What faculty would like a university to do is to make academics clearly the number one priority and everything else is secondary. And if they sent that message consistently, faculty would probably be ok with athletics. If it was more like intramural athletics. No faculty really cares about that because it doesn't impact their studies and nobody is making a whole lot of money in intramural athletics, so you don't have all of that potential problem. Whenever money enters the situation, weird things can happen. Even if you're careful, you get thousands and thousands of people who really care about the result of the game and if they got money, it's hard to police that perfectly.

For intellectual elitists, an ideal model for athletics is where academics is truly the priority and student-athletes are fully integrated into the institutions. There are some sports where studentathletes are better integrated in the institution, but the revenue-generating sports do not allow that opportunity. Furthermore, faculty intellectual elitists are concerned that revenue-generating sports result in institutions focusing on winning to produce more money, making academics secondary.

Some of the views of intellectual elitists can be attributed to personal feelings toward athletics. The emotional dimension describes the feelings behind the attitude toward the matter (Piderit, 2000). For example, the professionalization of athletics can make faculty feel less valued. "A coach should never be paid a million dollars. He was getting paid more than my faculty combined in salary. That's just ridiculous," as Professor Welfare stated. Professor Equity gave additional insight on reasons why faculty may feel devalued due to the attention athletics receives.

Sometimes I think the faculty feel like they don't have - they should have the upper hand, but they don't because they don't own a bunch a money or TV time. No one is going to bring GameDay to campus to talk about the latest guy in physics who did something really cool. It's just not gonna happened. And no one is gonna really throw \$2 million dollars his way. He may get a big grant for his machine but he's not going to make any money off of that. So there's a lot more popular support on the athletics side of the house and I think faculty sometimes feel like they constantly have to fight that, sort of keep that at bay.

Professor Ethics provided additional understanding behind the emotions, "There's lots of questions in the mind of an ordinary faculty member who sits in an office and has trouble getting supplies needed for his or her classes, they may look at athletics in a different way." The commercialization of athletics has resulted in feelings that coaches are more valuable than faculty. When faculty do 
not receive accolades, proper resources, and high pay, but see coaches receiving large compensation packages, it causes feelings of being undervalued. Furthermore, the differing values of academics and athletics results in faculty feeling their institution makes athletics a priority over academics, as Professor Welfare shared:

There is no coach whose value is based on winning or losing, who's gonna care much about the classroom. He's just not and they shouldn't obviously. Just like I wouldn't and so I'm not criticizing him. I think the model of the coach as sort of part of the student's scholars - the student-athlete's life has disappeared. I think the coach — and they're never gonna admit this and the spin you get in the media is never gonna say this. I think the coach blatantly is interested in the athletic part of the student-athlete and is only interested in the student part because of eligibility. Not because they don't think college is important. Not because they don't want them to graduate because frankly their future and their coach's is based on what happens on Saturdays and not what happens on Mondays through Fridays.

The emotional dimension highlights the feelings behind the intellectual elitist views of athletics. Faculty feel undervalued due to lack of recognition and resources and their perceived beliefs of the success of athletics further affirms those feelings.

The resistance to the growth and changes of athletics could be attributed to the large disconnect between academics and athletics. Most faculty have little interaction with the athletic department at BRU. "I don't know for most faculty if they would recognize the last three athletic directors if they saw them for instance, or the associate athletic directors," Professor Integrity expressed. For faculty that have student-athletes in their classes, they interact with staff in the student-athlete academic center, but not with athletic administrators. As a result of limited interaction with the athletic department, faculty may have negative perceptions of athletics as shared by a few of the participants:

One of the ways I think you have trust is if everybody knows everybody. But those folks in athletics, nobody knows who they are, they're suspicious of everything they do, and it's happening the other way around too...Hardly any of our faculty participated in intercollegiate athletics, right. So there's just a background difference right there that makes it hard for this friendliness and trust to develop, I think." (Professor Integrity) More faculty are far removed from football and particularly don't care. In the early 80s, '81, '82, I heard that lots of faculty supported, they had season tickets or they did stuff. I hear very little of that anymore and I don't know and that's just in this department, but I don't hear much of faculty being strong football fans. They like when BRU wins, but being strong football fans, no. (Professor Welfare)

There's always, always tension, and I think most faculty at BRU don't really know a whole lot about athletics, but they don't like that there's so much attention paid to it. They suspect it's probably costing them money and revenue and they rather avoid it as much as possible. If you ever put anything to a vote with faculty involving athletics, the faculty will almost always going to vote that athletics shouldn't be done or should be less emphasized. (Professor Equity) 
The mistrust between athletics and academics continues, but the limited interaction over time has resulted in faculty being less connected to athletics than they were in the past. Specifically at BRU, athletics and academics worked closely together in the 80s and 90s in order to better support student-athletes and to prevent future violations. While there were still critics, faculty and athletic staff had a better relationship because they interacted more with each other. BRU has not been in any trouble, but the continuous commercialization of athletics, such as new facilities, has pushed athletics farther away from the campus and less connected to academics.

This theme highlighted faculty views that posit how athletics has a negative impact on institutions. These views fall under intellectual elitism, which asserts that the professionalization of athletics (especially in high-profile sports) undermines the academic mission and values of higher education institutions. It also results in feelings of faculty being undervalued and not respected due to having to concede to the demands of athletics. Not only are faculty under this theme concerned that athletics receives more attention than academics, they are also concerned that student-athletes are negatively impacted due to athletics taking a priority over academics. As a result, faculty who are intellectual elitists resist the ever-changing scope of athletics.

\section{Academic Capitalists: Faculty Perceptions as Adapters of Change}

While intellectual elitists may believe the professionalization of athletics hurts the academic mission of institutions, academic capitalists believe athletics has a positive impact. Faculty that hold academic capitalism views adapt to the growth of athletics due to the perceived benefits it has on institutions. For example, academic capitalists argue that athletic scholarships give students an opportunity to receive a valuable education (Sack, 2009), as shared by Professor Integrity:

I would say that college athletic scholarships probably afforded more opportunities for higher education than any other things. We have 85 football players on scholarship, we got whatever number of baseball players, they don't all get a full scholarship, basketball and so forth. And a large percentage of those students if they didn't have that athletic support, they would either not be here or they would be on loans and all the other hardships. I think it's a huge benefit there, very large.

Athletic scholarships relieve the financial burden of college for student-athletes, who may or may not have the means to pay for college. The views of academic capitalists can often fall under Piderit's (2000) last dimension of intention, which focuses on both intention and behavior of change. This dimension not only considers the cognitive and emotional aspects of change, but also the intention behind the change. Under the intentional dimension, faculty believe that athletics not only benefits student-athletes, but the changing landscape of athletics also directly benefits institutions:

I think the fact that some athletic funds are used to help support academic programs and academic infrastructure, is an important thing that you may not have at every campus. I think the academic part of the university recognizes that there's some direct benefit support from the athletic department. As well as most of us realize strong athletic programs, visible athletic programs definitely help the university recruit better students 
and be a stronger university. Recruiting better students who are not athletes because of the visibility of the athletic program, so I think that helps that positive relationship and certainly my perception of the fact that there is a good relationship between academics and athletics. (Professor Alliance)

I think faculty don't always fully appreciate what athletics does bring to the school. It may be that students spend too much time thinking about football. But on the other hand, going to a school that has a real athletics program, makes it more enjoyable. That's part of the college experience. I actually like being at a school that has a football team that can compete for a national championship. You know it's not the biggest thing in the world but it's kind of cool. And whether we like it or not, whether the world should be this way or not, the fact of the matter is when our football team does well, our applications go up dramatically. And what that allows us to do is be more selective about who we admit, which means that the student body is better, which makes our research better. Maybe in a perfect world, people wouldn't think that way, but this is not a perfect world, so people think that way. So athletics gives back to BRU in ways that I think a lot of faculty don't appreciate. Now it also takes away and if there is a major scandal, you can argue that's a huge cost to our reputation that we can't get back. (Professor Equity)

Institutions that are competitive in athletics creates high visibility and attraction, which can result in increased number of applications for enrollment. While competitive athletics results in recruiting better student-athletes, academic capitalists believe it also results in recruiting better students due to the increased competition to enroll.

While some faculty believe athletics plays an important role in the institution, they also acknowledge that institutions have to adapt to the commercialization of athletics to remain competitive. Professor Integrity stated, "In many ways athletics has been involved in an arms race. We build fancy facilities that we don't really need in order to attract coaches and student-athletes." Professor Integrity continued to share, along with Professor Equity, concerns of being part of the athletics arms race:

Philosophically, I think athletics is a good component and I don't see it as a complement. I see an athletics programs, an athletics competition, to be part of the institution. But now, we've gotten to this point where there is truly a distortion in that relationship. And the distortion is the public interest in football/basketball and the money involved. And the fact that the money is primarily going into coaches' salaries and absorbed in extravagant facilities and not really going into the institution. It's just feeding that thing. I think at the very least it would be really hard for a school like BRU to separate athletics from academics unless everyone else were doing it too. Cause what you're basically asking BRU to do is unilaterally disarm in the race to get good students, and to some extent good faculty, but really good students. And that's hard to see how that would ultimately be in our best interest. Again, like it or not, it attracts students. That being said, I think you have to be very careful to make sure there's as many firewalls as possible so that the money pouring into athletics doesn't have a bad influence on academics and that the athletic people don't sort of encroach on the purposes of the academic side. I think it can be done and I think BRU does a pretty good job of doing it. But it's a constant 
struggle, because there's a constant pressure from the athletic side to get more involved and they've got the money to make that happen.

The professionalization of athletics can negatively impact academics as intellectual elitists argue; however, academic capitalists believe that not participating in commercialism will ultimately hurt institutions. Even if institutions wanted to reduce the commercialism of athletics, presidents understand the power of athletics in recruiting students and financial support from alumni and corporations.

In the cognitive dimension of adapting change in athletics, participants discussed how they believed faculty at BRU do not have strong feelings toward athletics and are overall accepting of the presence of athletics. Faculty Ethics shared an example of how a typical tension between athletics and academics was not an issue at BRU:

It was after a very tight budget year, where some academic building projects had to be put on the back burner, but athletics continued construction of their capital improvement projects. Well on many campuses, that would be an outrage for faculty. It wasn't an issue here and I told the athletics staff the reason I thought that was the case is there's no reason to be upset at us. If we broken a bunch of NCAA rules, we're on probation, our academics are poor, people would be looking at us and saying, "They're building an empire while everybody else is starving." But that isn't the case; it hasn't been the case here. So I think the relationship is good, but it's always continuous.

One of the main reasons faculty have been accepting of athletics at BRU is due to the improved academic performances of student-athletes and how the athletic department has not been involved in any scandals since the 90s:

Over time, I think the faculty has become more accepting of the role of athletics. It's huge. And they're pretty good here and they follow the rules and their academics are good, so there's no reason really for the faculty to be up in arms about athletics.

BRU, I would say is probably not average for a large football school kind of place. I think, this is my personal opinion, I don't know how representative it is of faculty. If you grant that we're a major football school and if you compare us to other major football schools, I think we actually do a pretty good job of setting the right tone that we're not just trying to win football games that the kids actually have to be students. I think we do a pretty good job of supporting them. I would be a little surprised if we had a major cheating scandal. It's not impossible, but I would be a little surprised hearing that from BRU. (Professor Equity)

So I think the attitude, as a student-athlete in many cases, is sort of the frontline of interface with the faculty and the fact that that's typically pretty good at BRU helps that opinion of the faculty of the athletic program and of the athletes. I think through the years having some not very good students who didn't pay much attention to their studies and just felt like they were there to participate in their sport, understandably developed the image of the dumb athlete who is not interested in being the true student-athlete. That's been there throughout and I think there's people who still feel that way. I think other than 
speaking to that, a university administration, faculty, and coaches addressing that repeatedly over the years to say as coaches, we're trying to recruit the best students we can, we encourage them to be truly students...Then I think that over time removes or reduces that stigma, because faculty see, other students see, the public sees that most of the participants in athletics are succeeding in the classroom and are successful students, and graduate. I think they've accomplished their objectives on their academic as well as their athletic side. (Professor Alliance)

Faculty believe BRU Athletics values that student-athletes receive a quality education. Since BRU has great academic performance scores, it helps reduce the negative perceptions. While there are faculty that may believe athletics is negatively impacting the academics of student-athletes, they typically are not very vocal about it at BRU. Participants did acknowledge that BRU may be unique as faculty at other institutions may not be as accepting of athletics.

The presence of intercollegiate athletics, along with its large fan bases across the nation, affirms the longstanding nature of athletics and why institutions are less likely to divest from them. Since athletics does not seem to be going anywhere, participants shared ways that may help other faculty embrace athletics:

Having an upper administrative team and university who sees a strong and varied athletic program being an important part of the whole university is a way that, you know, an upper administration, the board of trustees and the faculty, that feel like they are here first and foremost for academic reasons can also help support and help encourage an athletic program. (Professor Alliance)

One of the advantages that athletics has is that they have a huge amount of money. So compared to the rest of the university, they're swimming in cash. And one of the things that athletics could do would be to devote a small percentage of the money to supporting academics directly. If they did that, I really think that would go a long way toward helping faculty see the benefit because the other benefits are kind of intangible. (Professor Equity)

If they have to generate all of their revenue, they have to be given some considerations that you don't have to give the mechanical engineering department. The business, so there are some differences there. Then the success of athletics is measured by wins and losses, championships, and things like that. And that's not the way the success of mechanical engineering is measured or physics or anything else. So there's a different sort of necessity associated with athletics than there is associated with all these other things. The fact that the necessities are different means that it might be disagreements, and separation and everything else. But, there's a difference in what you do if you are running athletics and if you're running mechanical engineering. So those differences aren't going to go away but if you have trust across there, then that's what we want. (Professor Integrity) 
A better understanding of how athletics operates may help faculty accept athletics over time. However, showing that athletics has a direct positive benefit on academics is the key to accepting athletics. As one of the participants shared, if athletics consistently financially supported academic initiatives, this can shift the perceptions of faculty to embrace athletics or to acknowledge some of the benefits it has on institutions.

This theme highlighted faculty views that athletics has a positive impact on institutions. Faculty attitudes under this theme fall under academic capitalism, where they believe athletics results in high visibility, increased student applications, and financial support on the academic side. As institutions have to find ways to sustain, many have to rely on athletics as their marketing arm to attract students and donors. Furthermore, athletic programs that value academics receive increased support from faculty to embrace the role of athletics. Faculty that are academic capitalists adapt the continuous growth and change of athletics for the benefit of their classrooms and the overall institutions.

\section{Discussion}

The purpose of this study was to engage in a multidimensional exploration of faculty perceptions of organizational change at a Division I big-time institution. The evolution of intercollegiate athletics has resulted in a large financial impact for associations, media outlets, corporations, and some institutions. The findings revealed faculty hold varied attitudes toward the changing environment of athletics through the growth of commercialization. Piderit's (2000) cognitive, emotional, and intentional dimensions inform how faculty beliefs, feelings, knowledge, and experiences impact their perceptions on the role athletics should have in institutions. Faculty perceptions fell under two of Sack's (2009) conceptual models of commercialized sports: (a) intellectual elitism and (b) academic capitalism. The findings revealed the two models have clashing assumptions on the relationship of commercialization of athletics to academic values, educational impact, and the overall mission of higher education (Sack, 2009). All of the participants with the exception of one identified with the academic capitalist lens. While four of the five participants made statements related to intellectual elitism, only one participant, Professor Welfare, truly identified more with the intellectual elitist lens.

Moreover, the aforementioned faculty perceptions reflected cognitive, affective, and intentional dimensions of attitudes (Piderit, 2000). From a cognitive dimension standpoint, some faculty felt athletics should not receive special treatment from academic departments because this occurrence would signal the devaluation of academics. For example, the reference to the negative impact of scheduling on student-athletes' academic performance underscore the belief that athletics was overemphasized. In addition to scheduling, additional aspects of the neoliberalism athletics sub-culture (Gayles et al., 2018) included recruiting tactics, coaches' salaries, and monies spent on athletic facilities arms race were highlighted by the faculty participants. The emotional dimension was illustrated when faculty contrasted the treatment of high-profile sports such as football and basketball (e.g., scheduling for TV broadcasting purposes, preferential treatment with course enrollment, etc.), which signaled to faculty that the success of these programs was paramount to institutional visibility whereas their (faculty) efforts were not as important. In particular, the emotional dimension emphasized that the divestment of resources away from academics for athletic enhancements did not align with the academic missions of BRU. The 
intentional dimension of attitudes was reflected in the fact that faculty acknowledged that the intention of athletics may be to enhance the student-athlete experience, but the behavior/organizational actions actually contribute to mixed results for the student-athletes and the institutional prestige overall. Interestingly, all faculty acknowledged the limited role or influence they had on the changes occurring within athletics.

In regards to previous literature, the intellectual elitists in the study echo the sentiments expressed by reform groups such as KCIA, COIA, and TDG in terms of their desire for athletics to be more integrated into the educational fabric of the institution (COIA, 2019; KCIA, 2019; TDG, 2019). Similar to the findings of Lawrence (2009), faculty at BRU did not want to have increased oversight over athletics, but rather wanted university administration to engage in leadership efforts that cultivated a stronger balance between academics and athletics. The academic capitalists were more in alignment with Brand's (2006) collegiate model of intercollegiate athletics. These faculty felt the benefits of the neoliberal capitalist culture in athletics throughout the U.S. and at BRU outweigh any and all detriments. In their minds, being able to enhance institutional visibility and providing opportunities to students who may or may not otherwise have been able to attend BRU actually furthers the educational mission as opposed to undermining it. Hence, the intentional dimension of attitudes exhibited by these faculty indicated how the institutional logic of commercialization was justified to reach educational goals. There are inherent issues with this perspective in that questionable ethical behavior can be exhibited to fulfill the end goal at all costs (see Dosh [2013] for detailed coverage of this phenomenon at Division I FBS/Power 5 institutions), which is common among teleological school of thought. Notwithstanding, it is important to acknowledge the existence of the intentional dimension of attitudes in connection to the prevailing ideological view of the collegiate model propagated by the NCAA (Brand, 2006).

\section{Implications for Policy and Practice and Future Research}

From this study, several implications for policy and practice can be derived. According to Piderit (2000), "[s]uccessful organizational adaptation is increasingly reliant on generating employee support and enthusiasm or proposed changes, rather than merely overcoming resistance" (p. 783). At universities, faculty are among the vital employees; therefore, soliciting their buy-in when organizational changes are being decided upon is recommended. One recommendation is to expand the role of FARs to include a diverse faculty athletics council who is involved in key decisions regarding athletic funding, athletics connection to the broader campus, and innovative ideas for athletic and academic collaborations. Another related recommendation is for the faculty athletics council to regularly review, discuss, and disseminate reports from reform groups such as KCIA, COIA, and TDG to assist with the decision-making processes at the institutional level to ensure optimal educational integrity is upheld. Faculty surveys, interviews, and focus groups should be administered before, during, and after major organizational changes are made within athletics to enhance transparency. Routine faculty and athletics staff meetings, including social gatherings, could facilitate more frequent interactions. As the faculty participants in the current study noted, the lack of interaction contributed to the lack of understanding across various units on campus. In addition to collecting and incorporating faculty perspectives, another recommendation is to consistently solicit feedback from the student-athletes themselves (current and former) to ascertain their beliefs, feelings, and understandings about organizational changes 
that impact their lives. This data could be collected by faculty and graduate students outside of athletics or an independent third party to minimize conflict of interest. Collectively, these recommendations could strengthen the organizational effectiveness at institutions of higher education and restore (or amplify, depending on the perspective) the balance between academics and athletics to ensure optimal student-athlete development.

As with all studies, we acknowledge the limitations associated with our inquiry and approaches. The study is specifically designed around the experiences of the participants at this site and therefore, is not generalizable across all institutions. Similar studies may provide different results based on type of institution, sports offered, and other factors. However, the study contributes to the limited and valuable research on faculty perspectives of intercollegiate athletics. Whereas previous research has examined faculty perspectives at the macro-level, such as NCAA policy changes, this study focused on faculty perceptions at the meso-level, focusing on institutional changes. Future research can expand this study by examining and exploring commercialization and organizational change through faculty ideologies at Division I Power 5 and Non-Power 5 schools. While the current study is not generalizable, studying other sites can help determine if institution type, relationship between academics and athletics, and the behavior of the athletic department plays a role in how faculty identify as intellectual elitists, academic capitalists, and/or athlete rights advocates.

\section{Conclusion}

The benefit of adopting a multidimensional view of attitudes towards organizational change enables the illumination of heterogeneous and complex perspectives concurrently. Faculty are not monolithic. Thus, adopting theoretical frameworks that account for this type of nuance facilitate more comprehensive understandings of context and consequences. Additionally, this framework and accompanying methodology underscore the value and benefit of engaging in democratic and egalitarian approaches to understanding organizational change. Similar to how faculty unions provide faculty with a platform and mechanism to exercise their agency for institutional change, the demographic and egalitarian approaches employed in this study offer a means for examining the diverse views among different faculty members. This robust inclusion can also benefit administrators by implementing institutional changes that take into account a range of perspectives on the proper role of athletics within higher education as opposed to only acknowledging a select few (i.e., academic capitalist view as a dominant narrative versus faculty who champion the athletes' rights view). This study provided faculty a platform to express their views, but until organizational changes incorporate their views in a substantive manner, the schism between academics and athletics will remain. 


\section{References}

Brand, M. (2006). The role and value of intercollegiate athletics in universities. Journal of Philosophy of Sport, 33, 9-20.

Brown, G. (2014). NCAA graduation rates: A quarter century of tracking academic success. NCAA website. Retrieved from http://www.ncaa.org/about/resources/research/ncaagraduation-rates-quarter-century-tracking-academic-success

Byers, W. (1995). Unsportsmanlike conduct: Exploiting college athletes. Ann Arbor, MI: The University of Michigan Press.

CAPA (2019). College athletes players association website. CAPA Home page. Retrieved from http://www.collegeathletespa.org/

CARE-FC (2019). College athletes rights and empowerment faculty coalition. CARE-FC Home page. Retrieved from http://care-fc.org/

Cockley, W., \& Roswal, G. (1994). A comparison study of faculty members' perceived knowledge and satisfaction regarding NCAA athletic programs. Journal of Sport Behavior, 17(4), 217.

COIA (2019). Coalition on intercollegiate athletics. Retrieved from https://www.thecoia.org

Cooper, J. N., Nwadike, A., \& Macaulay, C. (2017). A critical race theory analysis of big-time college sports: Implications for culturally responsive and race-conscious sport leadership. Journal of Issues in Intercollegiate Athletics, 10, 204-233.

Creswell. J. W. (2007). Qualitative inquiry and research design: Choosing among five approaches (2nd ed.). Thousand Oaks, CA: Sage.

Dosh, K. (2013). Saturday millionaires: How winning football builds winning colleges. New York, NY: Turner Publishing Company/Wiley General Trade.

Duderstadt, J. J. (2003). Intercollegiate athletics and the American university. Ann Arbor, MI: University of Michigan Press.

Engstrand, G. (1995). Faculty control of athletics: A case study of the University of Minnesota. Unpublished doctoral dissertation. University of Minnesota.

Gayles, J. G., Comeaux, E., Ofoegu, E., \& Grummert, S. (2018). Neoliberal capitalism and racism in college athletics: Critical approaches for supporting student-athletes. New Directions for Student Services, 163, 11-21.

Gordon, J. (2006). Critical friendship. Medical Education, 40, 5-6. 
Harper, M., \& Cole, P. (2012). Member checking: Can benefits be gained similar to group therapy? The Qualitative Report, 17(2), 510-517.

KCIA (2019). Knight commission on intercollegiate athletics. Retrieved from https://www.knightcommission.org/

Lawrence, J., Ott, M., \& Hendricks, L. (2009). Athletics reform and faculty perceptions. New Directions for Higher Education, 148, 73-81.

Moustakas, C. (1994). Phenomenological research methods. Thousand Oaks, CA: Sage.

Muscato, A., Branch, T., \& Foxworth, D. (Producers), \& Finkel, R., Martin, T., \& Paley, J. (Directors). (2013). Schooled: The price of college sports. [Documentary]. United States: Strand Releasing.

NCAA (2019). Divisional differences and the history of multidivisional classification. NCAA website. Retrieved from http://www.ncaa.org/about/who-we-are/membership/divisionaldifferences-and-history-multidivision-classification

Nwadike, A.C. Baker, A.R., Brackenbusch, V.B., \& Hawkins, B.J. (2016). Institutional racism in the NCAA and the racial implications of the "2.3 or take a knee" legislation. Marquette Sports Law Review, 26(2), 523-543.

Patton, M. Q. (2002). Qualitative research \& evaluation methods ( $3^{\text {rd }}$ ed.). Thousand Oaks, CA: Sage Publications.

Piderit, S. K. (2000). Rethinking resistance and recognizing ambivalence: A multidimensional view of attitudes toward an organizational change. The Academy of Management Review, 25(4), 783-794.

Ridpath, B. D. (2018). Alternative models of sports development in America: Solutions to a crisis in education and public health. Athens, $\mathrm{OH}$ : Ohio University Sport Management Press.

Sack, A. (2009). Clashing models of commercial sport in higher education: Implications for reform and scholarly research. Journal of Issues in Intercollegiate Athletics, 2, 76-92.

Sack, A., \& Staurowsky, E. J. (1998). College athletes for hire: The evolution and legacy of the NCAA's amateur myth. Westport, CT: Praeger.

Sapakoff, G. (2008). Clemson's innovative, imitated Vickery Hall helped educate athletes, change school's academic image. The Post and Courier. Retrieved from https://www.postandcourier.com/news/clemson-s-innovative-imitated-vickery-hallhelped-educate-athletes-change/article_135308c5-a260-5a0e-b963-41eda5cac9fb.html

Schwarz, A. (2011). Excuses, not reasons: 13 myths about (not) paying college athletes. In S. Barbieri (Ed.), Selected Proceedings of the Santa Clara University Sports Law 
Symposium (pp. 46-74).

Sokolowski, R. (2000). Introduction to phenomenology. New York, NY: Cambridge University Press.

Southall, R., \& Nagel, M. S. (2010). Institutional logics theory: Examining big-time college sport. In E. Smith (Ed.), Sociology of sport and social theory (pp. 67-79). Champaign, IL: Human Kinetics.

Sperber, M. (2000). Beer and circus: How big-time college sports is crippling undergraduate education. New York, NY: Henry Holt and Company.

Stotlar, D. K. (2013). Developing Successful Sport Marketing Plans (Fourth Ed.). Morgantown, WV: Fitness Information Technology.

TDG (2019). The Drake group. Retrieved from https://thedrakegroup.org/

Teddlie, C., \& Yu, F. (2007). Mixed methods sampling: A typology with examples. Journal of Mixed Methods Research, 1, 77-100.

Thelin, J. (1994). Games colleges play: Scandal and reform in intercollegiate athletics. Baltimore, MD: Johns Hopkins University Press.

Yin, R. K. (2003). Applications of case study research ( $2^{\text {nd }}$ ed.). Thousand Oaks, CA: Sage.

Yin, R.K. (2006). Case study methods. In J. Green, G. Camilli, \& P. Elmore (Eds.), Complementary methods in educational research (pp. 111-122). Mahwah, NJ: Lawrence Associates.

Zimbalist, A. (2001). Unpaid professionals. Princeton, NJ: Princeton University Press. 